\title{
MULTIVARIATE CALIBRATION TECHNIQUE FOR THE SPECTROPHOTOMETRIC QUANTIFICATION OF IVERMECTIN IN PHARMACEUTICAL FORMULATION
}

\author{
MADHAN S, KAVITHA J*, LAKSHMI KS \\ Department of Pharmaceutical Analysis, SRM College of Pharmacy, SRM Institute of Science and Technology, Kancheepuram, Tamil Nadu, \\ India. Email: kavitha0208@gmail.com
}

Received: 30 October 2018, Revised and Accepted: 14 November 2018

\begin{abstract}
Objective: The present abstract makes the use of multivariate calibration technique for the quantification of ivermectin in pharmaceutical dosage form.

Methods: Multivariate calibration technique is based on the use of linear regression equations, by correlating the relation between concentration and absorbance at seven different selected wavelengths. The $\lambda_{\max }$ of ivermectin was found to be $245 \mathrm{~nm}$. The results were treated statistically. This statistical approach gives optimum results by eliminating the fluctuations arising from the instrumental or experimental conditions.

Results: The developed method was validated as per the ICH guidelines and was found to be simple, linear, accurate, precise, and reproducible. The method was found to be linear over a concentration range of $5-15 \mu \mathrm{g} / \mathrm{mL}$ with a correlation coefficient $\left(r^{2}\right)$ value of about 0.9998 . The limit of detection and quantification were found to be 0.029 and $0.087 \mu \mathrm{g} / \mathrm{mL}$, respectively. The percentage relative standard deviation for intraday and interday precision was found to be in the range of $0.473-1.373$ and $0.301-1.617$, respectively. The percentage recovery was found within the range of $97.60-101.80 \% \mathrm{w} / \mathrm{w}$.
\end{abstract}

Conclusion: The results evidence that a simple, linear, precise, accurate, sensitive, and reproducible multivariate calibration technique has been developed and validated for the quantification of ivermectin in bulk and pharmaceutical formulation.

Keywords: Ivermectin, ICH guidelines, Multivariate calibration technique, Pharmaceutical formulation, Validation.

(C) 2019 The Authors. Published by Innovare Academic Sciences Pvt Ltd. This is an open access article under the CC BY license (http://creativecommons. org/licenses/by/4. 0/) DOI: http://dx.doi.org/10.22159/ajpcr.2019.v12i2.29416

\section{INTRODUCTION}

Ivermectin (Fig. 1) (N-[3-(3-cyanopyrazolo [1,-5-a] pyrimidin-7-yl) phenyl]-N-ethylacetamide) is a pyrazolopyrimidine derivative that acts as an effective hypnotic and selectively binds to the $\alpha 1$ benzodiazepine receptors [1]. It is being used for treating certain worm infections, onchocerciasis (river blindness), and some types of diarrhea (strongyloidiasis). It paralyzes and kills the offspring of adult worms which slowdowns the rate of reproduction of the adult worm that results in fewer worms in skin, eyes, and blood [2]. Its molecular formula is $\mathrm{C}_{17} \mathrm{H}_{15} \mathrm{~N}_{5} \mathrm{O}$ and has a molecular weight of about $305.33 \mathrm{~g} / \mathrm{mol}$ [3]. The drug is official in Indian, British, and the United States Pharmacopoeia. The literature survey reveals on the reported methods for the determination of ivermectin which includes spectrophotometry [4], capillary electrophoresis [5], highperformance thin-layer chromatography [6], high- performance liquid chromatography (LC) [7], LC-tandem mass spectrometry (MS) [8], and a gas chromatography-MS [9] either in pharmaceutical formulations or in biological fluids.

Spectrophotometric methods due to their inherent rapidity, simplicity of procedures, and low cost of the technique are employed as the favorable method in most of the laboratories $[10,11]$. The opted method is based on the direct determination of ivermectin with high range of accuracy and precision. The method is simple, economical and can be applied to estimate ivermectin in bulk drug and pharmaceuticals. The proposed method characterizes the use of UV spectral multivariate calibration technique employing simple mathematical contents for the estimation of ivermectin in pharmaceutical dosage form.

Multivariate calibration represents the conversion of single common species analysis from one dependent variable to " $m$ " dependent variables, for example, wavelengths or sensors, which can be simultaneously included in the calibration model [12]

Under optimized conditions, the functional statistical method gives appreciable resolving power, sensitivity, rapidity and low cost for the quantitative analysis, quality control, and routine analysis of the investing compounds [13].

The absorbance of an analyte $(\mathrm{X})$ is measured at five wavelengths set $(\lambda=226,228,230,232$, and $234 \mathrm{~nm})$, the following equation can be written for individual selected wavelength.

$\mathrm{A} \lambda_{226}=\mathrm{aXC}_{\mathrm{x}}+\mathrm{k}_{1}$

$\mathrm{A} \lambda_{228}=\mathrm{bXC}_{\mathrm{x}}+\mathrm{k}_{2}$

$\mathrm{A} \lambda_{230}=\mathrm{cXC}_{\mathrm{x}}+\mathrm{k}_{3}$

$\mathrm{A} \lambda_{232}=\mathrm{dXC}+\mathrm{k}_{4}$

$\mathrm{A} \lambda_{234}=\mathrm{eXC}_{\mathrm{x}}+\mathrm{k}_{5}$

Where, $A \lambda$ represents the absorbance of the analyte; $a, b, c, d$, and e are the slopes of the linear regression functions of the analyte; $\mathrm{k}_{1}, \mathrm{k}_{2}, \mathrm{k}_{3}, \mathrm{k}_{4}$, and $k_{5}$ are the intercepts of the linear regression functions at the five selected bandwidth and $\mathrm{C}_{\mathrm{x}}$ represents the concentration of the analyte. The above five equation systems (1-5) can be summarized as follows:

$\mathrm{A}_{\mathrm{T}}=\mathrm{axC}_{\mathrm{x}}+\mathrm{bxC}_{\mathrm{x}}+\mathrm{cxC}_{\mathrm{x}}+\mathrm{dxC}_{\mathrm{x}}+\mathrm{exC}_{\mathrm{x}}+\mathrm{K}_{\mathrm{T}}$

Which can be further simplified to

$A_{T}=C_{x}(a+b+c+d+e)+K_{T}$ 


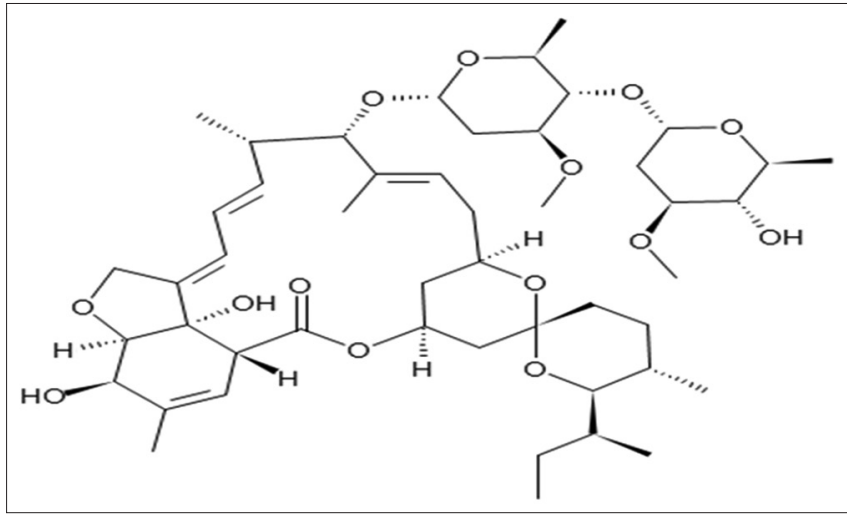

Fig. 1: Chemical structure of ivermectin

Where, $A_{T}$ and $K_{T}$ represent the sum of the absorbance obtained and the sum of intercepts of regression equations at five wavelength set, respectively. The concentration of the analyte $\mathrm{X}$ in a solution can be calculated using the equation:

$$
C_{x}=\frac{A_{T}-K_{T}}{(a+b+c+d+e)}
$$

\section{Experimental}

\section{Chemicals and solvents}

- Distilled water

- Ethanol

- The reference standard of ivermectin was obtained as gift sample from Pondchy Pharmaceuticals, Puducherry. The marketed tablet formulation used was rapimec (label claim - $10 \mathrm{mg}$ of Ivermectin), from the same pharmaceutical company.

\section{Solubility}

- Very freely soluble in methanol, ethanol, acetone, ethyl acetate, and acetonitrile.

\section{Instrumentation}

- Labindia UV-visible double beam spectrophotometer

- Sonicator

- Electric balance.

\section{Method development}

\section{Selection of solvent}

Ivermectin was freely soluble in ethanol which was used as the solvent to solubilize the standard drug and the sample as well.

Preparation of standard stock solution

The standard stock solution of ivermectin was prepared by dissolving $10 \mathrm{mg}$ of the drug in $10 \mathrm{~mL}$ of the solvent to obtain a concentration of $1 \mathrm{mg} / \mathrm{mL}$. The above solution was further diluted to get concentrations in the range of $5-15 \mu \mathrm{g} / \mathrm{mL}$.

Determination of $\lambda_{\max }$

The stock solution of ivermectin was diluted with the solvent to get a concentration of $10 \mu \mathrm{g} / \mathrm{mL}$. This solution was scanned in the UV region from 400 to $200 \mathrm{~nm}$. The $\lambda_{\max }$ was found to be $245 \mathrm{~nm}$ (Fig. 2).

Preparation of sample solution

A total of 20 tablets of ivermectin were weighed and the contents were transferred into a mortar, powdered, and mixed well. A weight equivalent to $10 \mathrm{mg}$ of ivermectin was weighed and dissolved in $5 \mathrm{~mL}$ of ethanol. The above solution was sonicated for $15 \mathrm{~min}$ and finally made up to the mark with ethanol, filtered, and diluted for further analysis.

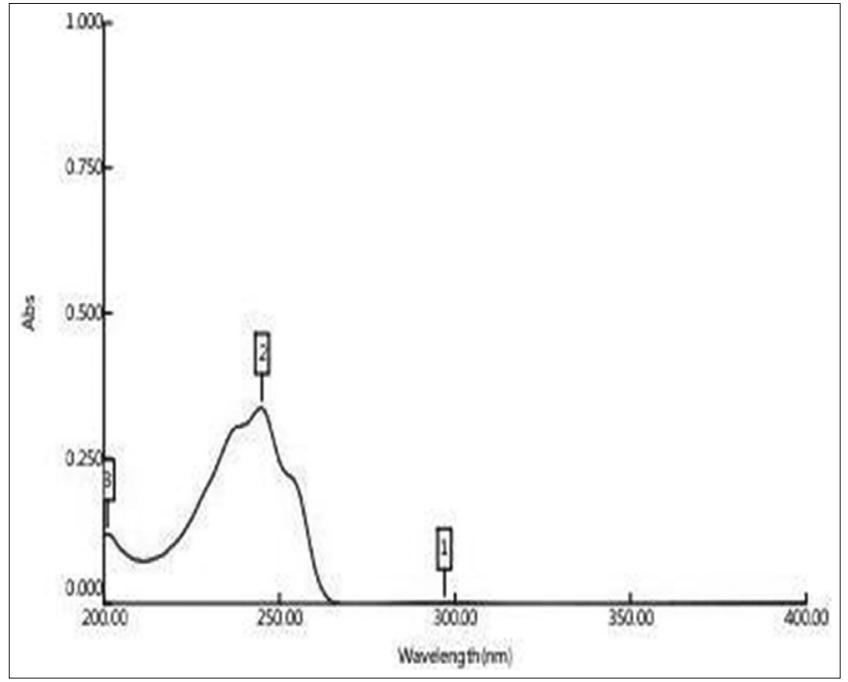

Fig. 2: UV spectrum of ivermectin

\section{Method validation}

The developed method was validated as per the ICH Q2 R1 guidelines to check validation parameters such as linearity, sensitivity, precision, and accuracy [14]

\section{Linearity}

Stock solution of ivermectin was diluted with the solvent to get a concentration in the range of $5-15 \mu \mathrm{g} / \mathrm{mL}$. Now, to develop correlation and to reduce the instrumental fluctuations, absorbance of the above solutions was recorded in several selected wavelengths around the $\lambda_{\max }$ of the drug $(245 \mathrm{~nm})$, that is, $239,241,243,245,247,249$, and $251 \mathrm{~nm}$.

The overlay UV spectra showing linearity at the $\lambda_{\max }(245 \mathrm{~nm})$ were represented in Fig. 3. The absorbance values of the five different selected concentrations were recorded and represented in Table 1. Linearity data showing system suitability parameters at the selected wavelengths are shown in Table 2.

The calibrations graphs and the residual plots at the seven selected wavelengths were represented in Figs. 4-10 and Figs. 11-17, respectively.

\section{Precision}

Intraday and interday precision was performed by measuring the absorbance of the solutions of concentration 5,10 , and $15 \mu \mathrm{g} / \mathrm{mL}$ at all the seven selected wavelengths. Each concentration was scanned 3 times a day (intraday precision) and for three different days (interday precision). The absorbance values recorded at the selected wavelengths for intraday and interday precision were provided in Tables 3 and 4. The SD and percentage relative standard deviation (RSD) values obtained at different wavelengths were calculated and represented in Tables 5 and 6 . The overlay UV spectra for intra- and inter-day precision are shown in Figs. 18 and 19.

Assay

The absorbance of the extracted sample solution was recorded at $245 \mathrm{~nm}$ and the amount of drug present in the formulation was estimated (Table 7).

\section{Accuracy (recovery studies)}

The accuracy of the developed method was evaluated by standard addition method at $80 \%, 100 \%$, and $120 \%$ of the selected concentration levels. From the prepared stock solutions of standard and sample, $0.4 \mathrm{~mL}$ of standard solution was pipetted into three different volumetric flasks and $0.1,0.6$, and $1.1 \mathrm{~mL}$ of the sample solution were added to the 
Table 1: Multivariate UV calibration at seven selected wavelengths

\begin{tabular}{|c|c|c|c|c|c|c|c|}
\hline \multirow[t]{2}{*}{ Concentration $(\mu \mathrm{g} / \mathrm{mL})$} & \multicolumn{7}{|c|}{ Absorbance (nm) } \\
\hline & 239 & 241 & 243 & 245 & 247 & 249 & 251 \\
\hline 5 & 0.158 & 0.160 & 0.167 & 0.171 & 0.158 & 0.135 & 0.119 \\
\hline 10 & 0.319 & 0.324 & 0.340 & 0.349 & 0.324 & 0.276 & 0.240 \\
\hline 12.5 & 0.402 & 0.408 & 0.426 & 0.437 & 0.405 & 0.346 & 0.301 \\
\hline 15 & 0.480 & 0.487 & 0.510 & 0.524 & 0.486 & 0.415 & 0.361 \\
\hline
\end{tabular}

Table 2: Linearity data showing system suitability parameters at the selected wavelengths

\begin{tabular}{|c|c|c|c|c|c|c|c|}
\hline Wave length (nm) & Regression equation & Slope & Intercept & $\%$ intercept & $r^{2}$ & $\operatorname{LOD}(\mu \mathrm{g} / \mathrm{mL})$ & LOQ $(\mu \mathrm{g} / \mathrm{mL})$ \\
\hline 239 & $y=0.0322 x-0.0026$ & 0.0322 & 0.0026 & 0.26 & 0.9999 & 0.039 & 0.117 \\
\hline 241 & $y=0.0328 x-0.0032$ & 0.0328 & 0.0032 & 0.32 & 0.9999 & 0.105 & 0.319 \\
\hline 243 & $y=0.0339 x-0.0028$ & 0.0339 & 0.0028 & 0.28 & 0.9990 & 0.068 & 0.206 \\
\hline 245 & $y=0.0353 x-0.0064$ & 0.0353 & 0.0064 & 0.64 & 0.9991 & 0.029 & 0.087 \\
\hline 247 & $y=0.0328 x-0.0046$ & 0.0328 & 0.0046 & 0.46 & 0.9999 & 0.019 & 0.058 \\
\hline 249 & $y=0.028 x-0.0026$ & 0.028 & 0.0026 & 0.26 & 0.9993 & 0.036 & 0.110 \\
\hline 251 & $y=0.0243 x-0.003$ & 0.0243 & 0.003 & 0.3 & 0.9999 & 0.034 & 0.104 \\
\hline
\end{tabular}

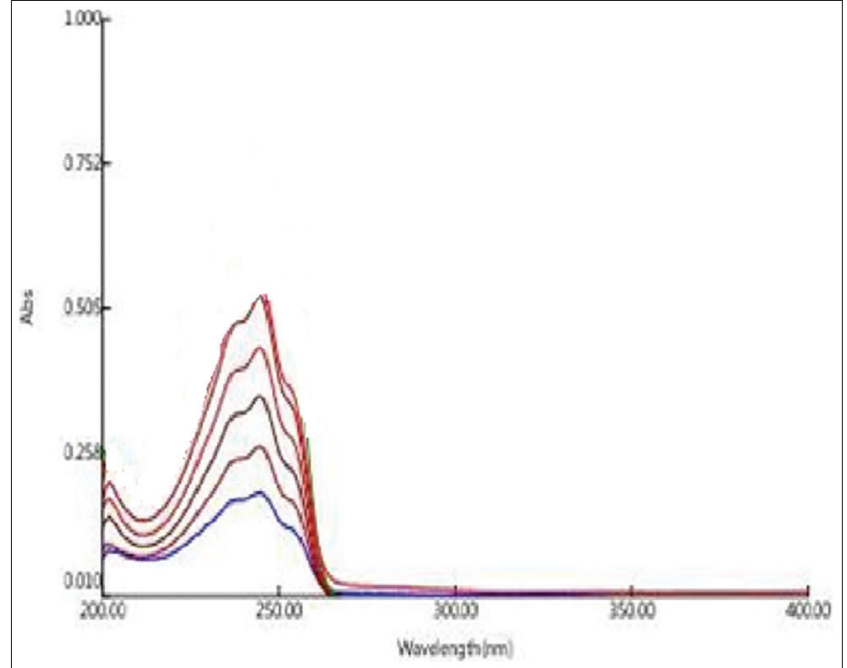

Fig. 3: Overlay UV spectrum showing linearity of ivermectin

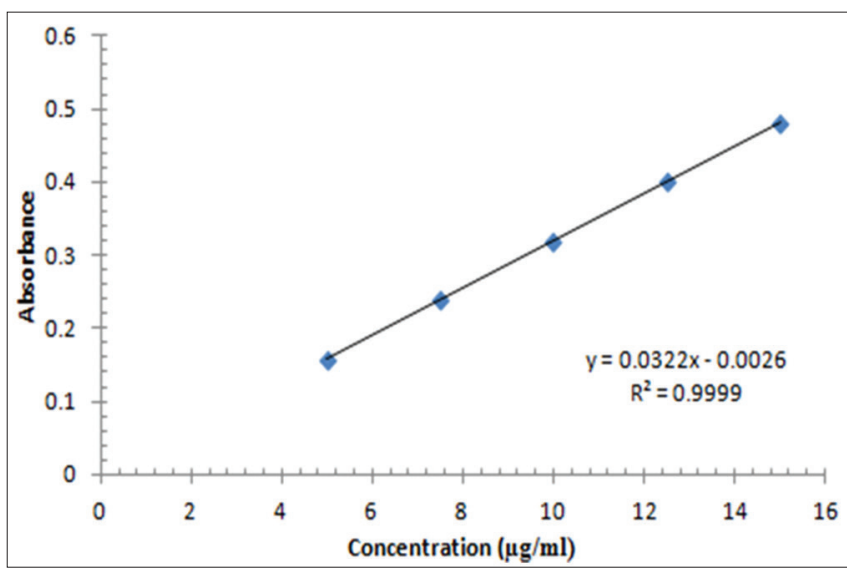

Fig. 4: Calibration graph at $239 \mathrm{~nm}$

above volumetric flasks and the volume was made up to $10 \mathrm{~mL}$ with ethanol. The percentage recovery values were calculated. The results representing recovery studies are shown in Fig. 20 and provided in Table 8.

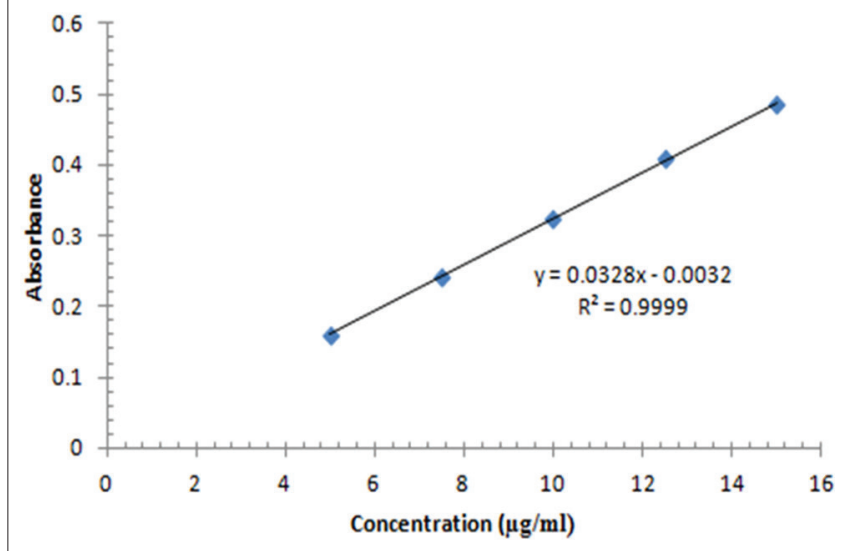

Fig. 5: Calibration graph at $241 \mathrm{~nm}$

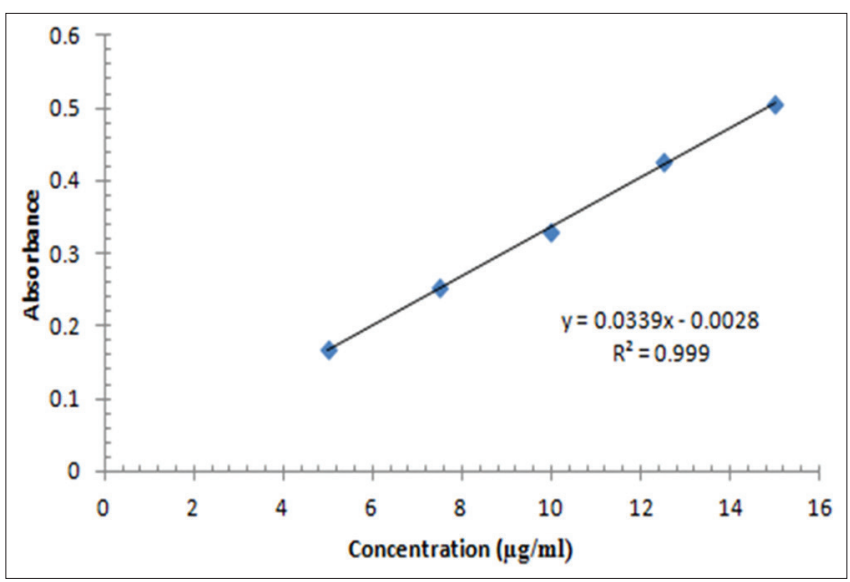

Fig. 6: Calibration graph at $243 \mathrm{~nm}$

\section{RESULTS AND DISCUSSION}

The $\lambda_{\max }$ of ivermectin was found to be $245 \mathrm{~nm}$ employing ethanol as the solvent (Fig. 2).

Linearity

The UV spectra showing linearity at $245 \mathrm{~nm}$ are represented in Fig. 3. The linearity for different prepared concentration of $5-15 \mu \mathrm{g} / \mathrm{mL}$ was 
Table 3: Absorbance values for intraday precision

\begin{tabular}{|c|c|c|c|c|c|c|c|c|}
\hline \multirow[t]{2}{*}{ Concentration $(\mu \mathrm{g} / \mathrm{mL})$} & \multirow[t]{2}{*}{ Number of repetitions } & \multicolumn{7}{|c|}{ Absorbance (nm) } \\
\hline & & 239 & 241 & 243 & 245 & 247 & 249 & 251 \\
\hline \multirow[t]{2}{*}{5} & 1 & 0.151 & 0.154 & 0.151 & 0.165 & 0.151 & 0.121 & 0.112 \\
\hline & 3 & 0.154 & 0.154 & 0.154 & 0.168 & 0.154 & 0.121 & 0.113 \\
\hline \multirow[t]{3}{*}{10} & 1 & 0.317 & 0.324 & 0.337 & 0.341 & 0.318 & 0.269 & 0.232 \\
\hline & 2 & 0.318 & 0.323 & 0.339 & 0.347 & 0.32 & 0.271 & 0.236 \\
\hline & 3 & 0.312 & 0.321 & 0.332 & 0.34 & 0.313 & 0.266 & 0.231 \\
\hline \multirow[t]{3}{*}{15} & 1 & 0.464 & 0.47 & 0.494 & 0.505 & 0.466 & 0.395 & 0.345 \\
\hline & 2 & 0.473 & 0.48 & 0.504 & 0.515 & 0.475 & 0.403 & 0.352 \\
\hline & 3 & 0.464 & 0.471 & 0.494 & 0.509 & 0.466 & 0.395 & 0.344 \\
\hline
\end{tabular}

Table 4: Absorbance values for interday precision

\begin{tabular}{|c|c|c|c|c|c|c|c|c|}
\hline \multirow[t]{2}{*}{ Concentration $\mu \mathrm{g} / \mathrm{mL}$ ) } & \multirow[t]{2}{*}{ Number of repetitions } & \multicolumn{7}{|c|}{ Absorbance (nm) } \\
\hline & & 239 & 241 & 243 & 245 & 247 & 249 & 251 \\
\hline \multirow[t]{2}{*}{5} & 1 & 0.141 & 0.142 & 0.150 & 0.157 & 0.141 & 0.120 & 0.101 \\
\hline & 3 & 0.140 & 0.141 & 0.151 & 0.153 & 0.142 & 0.121 & 0.102 \\
\hline \multirow[t]{3}{*}{10} & 1 & 0.300 & 0.303 & 0.332 & 0.331 & 0.310 & 0.255 & 0.220 \\
\hline & 2 & 0.305 & 0.301 & 0.333 & 0.334 & 0.315 & 0.261 & 0.222 \\
\hline & 3 & 0.300 & 0.302 & 0.331 & 0.340 & 0.310 & 0.255 & 0.221 \\
\hline \multirow[t]{3}{*}{15} & 1 & 0.460 & 0.465 & 0.490 & 0.500 & 0.460 & 0.392 & 0.343 \\
\hline & 2 & 0.472 & 0.462 & 0.500 & 0.515 & 0.475 & 0.403 & 0.352 \\
\hline & 3 & 0.460 & 0.451 & 0.492 & 0.509 & 0.466 & 0.395 & 0.344 \\
\hline
\end{tabular}

Table 5: Intraday precision

\begin{tabular}{|c|c|c|c|c|c|c|c|c|}
\hline Concentration $(\mu \mathrm{g} / \mathrm{mL})$ & Description & $239 \mathrm{~nm}$ & $241 \mathrm{~nm}$ & $243 \mathrm{~nm}$ & $245 \mathrm{~nm}$ & $247 \mathrm{~nm}$ & $249 \mathrm{~nm}$ & $251 \mathrm{~nm}$ \\
\hline \multirow[t]{3}{*}{5} & Mean & 0.152 & 0.153 & 0.153 & 0.166 & 0.152 & 0.122 & 0.112 \\
\hline & SD & 0.002 & 0.001 & 0.002 & 0.002 & 0.002 & 0.001 & 0.001 \\
\hline & $\%$ RSD & 1.373 & 0.753 & 1.001 & 0.918 & 1.373 & 0.949 & 0.893 \\
\hline \multirow[t]{3}{*}{10} & Mean & 0.316 & 0.323 & 0.336 & 0.343 & 0.317 & 0.269 & 0.233 \\
\hline & SD & 0.003 & 0.002 & 0.004 & 0.004 & 0.004 & 0.003 & 0.003 \\
\hline & $\%$ RSD & 1.018 & 0.473 & 1.073 & 1.105 & 1.137 & 0.937 & 1.136 \\
\hline \multirow[t]{2}{*}{15} & Mean & 0.467 & 0.474 & 0.497 & 0.510 & 0.469 & 0.398 & 0.347 \\
\hline & $\%$ RSD & 1.113 & 1.163 & 1.161 & 0.988 & 1.108 & 1.161 & 1.256 \\
\hline
\end{tabular}

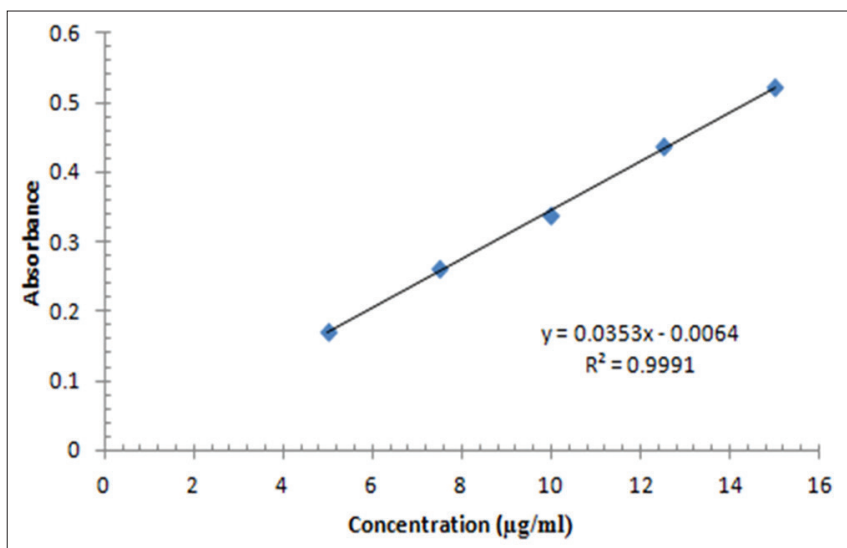

Fig. 7: Calibration graph at $245 \mathrm{~nm}$

recorded at the selected wavelengths of about $239,241,243,245,247$, 249, and $251 \mathrm{~nm}$. The observed results were tabulated in Table 1.

All the calibration curves were found to be linear over the selected concentration range of about 5-15 $\mu \mathrm{g} / \mathrm{mL}$. The linear regression

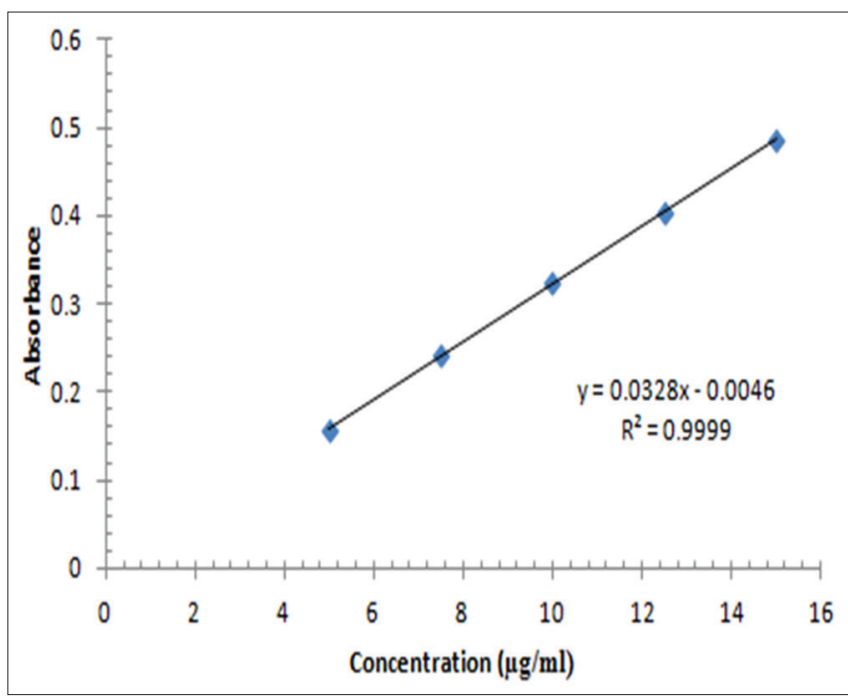

Fig. 8: Calibration graph at $247 \mathrm{~nm}$

analysis data of the constructed calibration plots showed good linear relation with a correlation coefficient $\left(r^{2}\right)>0.998$. The calibration 
Table 6: Interday precision

\begin{tabular}{|c|c|c|c|c|c|c|c|c|}
\hline Concentration $(\mu \mathrm{g} / \mathrm{mL})$ & Description & $239 \mathrm{~nm}$ & $241 \mathrm{~nm}$ & $243 \mathrm{~nm}$ & $245 \mathrm{~nm}$ & $247 \mathrm{~nm}$ & $249 \mathrm{~nm}$ & $251 \mathrm{~nm}$ \\
\hline \multirow[t]{3}{*}{5} & Mean & 0.141 & 0.142 & 0.151 & 0.154 & 0.142 & 0.121 & 0.101 \\
\hline & SD & 0.002 & 0.001 & 0.001 & 0.002 & 0.001 & 0.001 & 0.001 \\
\hline & $\%$ RSD & 1.081 & 0.408 & 0.662 & 1.496 & 0.704 & 0.826 & 0.570 \\
\hline \multirow[t]{3}{*}{10} & Mean & 0.302 & 0.302 & 0.332 & 0.335 & 0.312 & 0.257 & 0.221 \\
\hline & SD & 0.003 & 0.001 & 0.001 & 0.005 & 0.003 & 0.003 & 0.001 \\
\hline & $\%$ RSD & 0.957 & 0.331 & 0.301 & 1.368 & 0.926 & 1.348 & 0.452 \\
\hline \multirow{2}{*}{15} & Mean & 0.464 & 0.459 & 0.494 & 0.508 & 0.467 & 0.397 & 0.346 \\
\hline & $\%$ RSD & 1.493 & 1.605 & 1.071 & 1.486 & 1.617 & 1.434 & 1.424 \\
\hline
\end{tabular}

Table 7: Assay of ivermectin

\begin{tabular}{lll}
\hline Label claim (mg) & Amount estimated (mg) & \% assay \\
\hline 10 & 9.86 & 9.87 \\
& 9.89 & 98.7 \\
& & 98.9 \\
Average & & 98.7 \\
SD & & 0.153 \\
\% RSD & & 0.154 \\
\hline
\end{tabular}

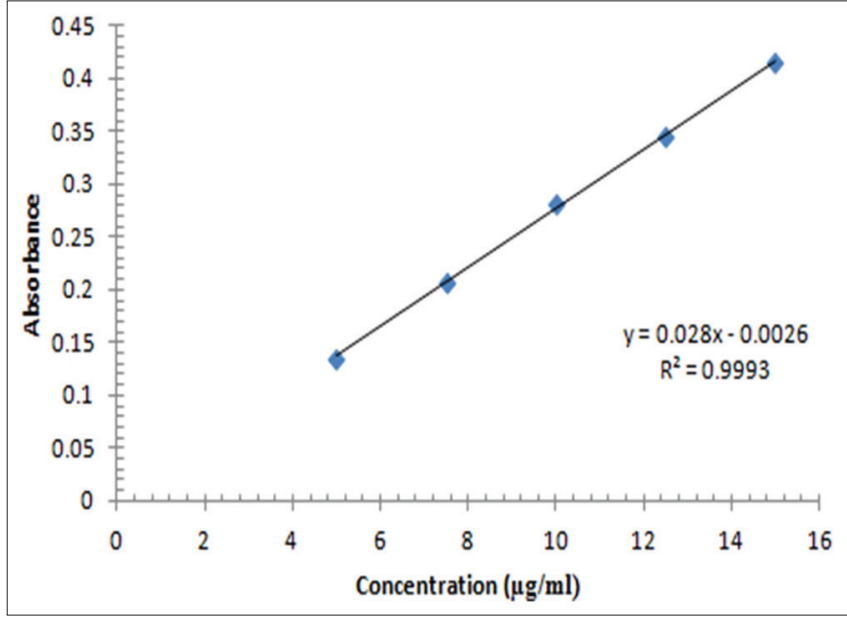

Fig. 9: Calibration graph at $249 \mathrm{~nm}$

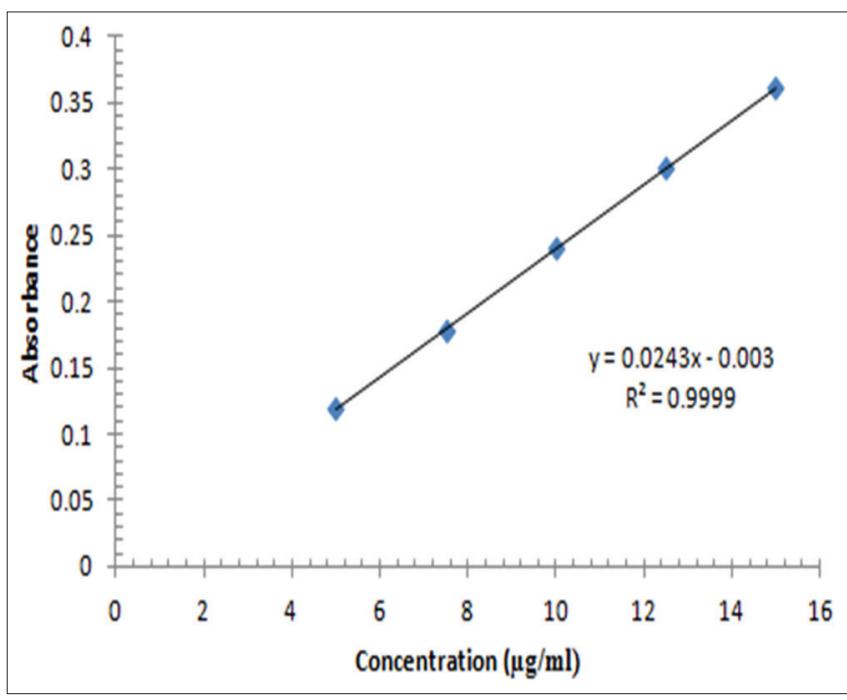

Fig. 10: Calibration graph at $251 \mathrm{~nm}$

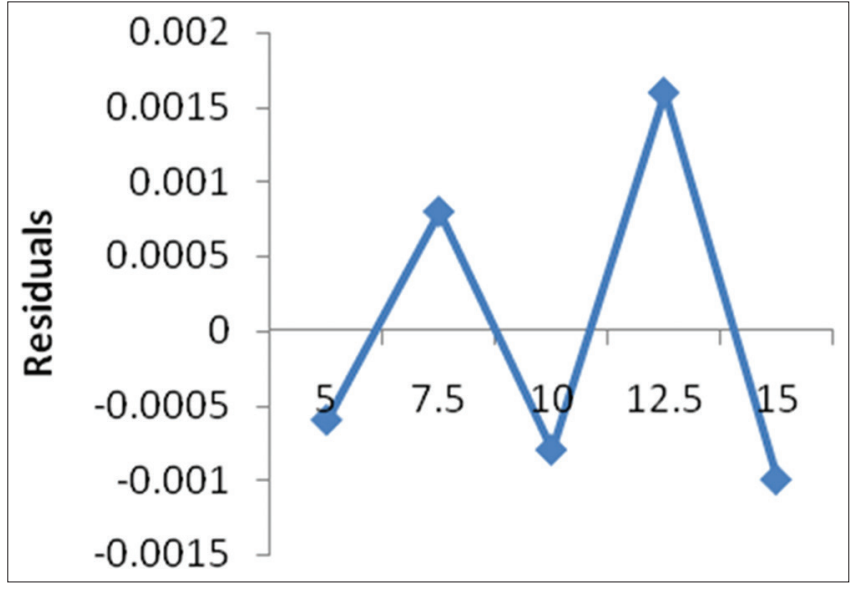

Fig. 11: Residual plot at $239 \mathrm{~nm}$

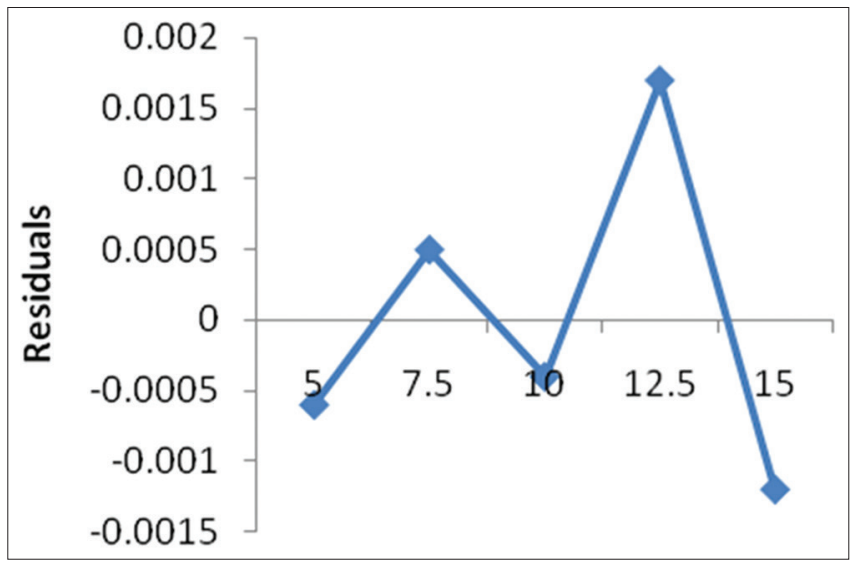

Fig. 12: Residual plot at $241 \mathrm{~nm}$

graphs and the system suitability parameters were presented in Figs. 4-17 and Table 2, respectively. 


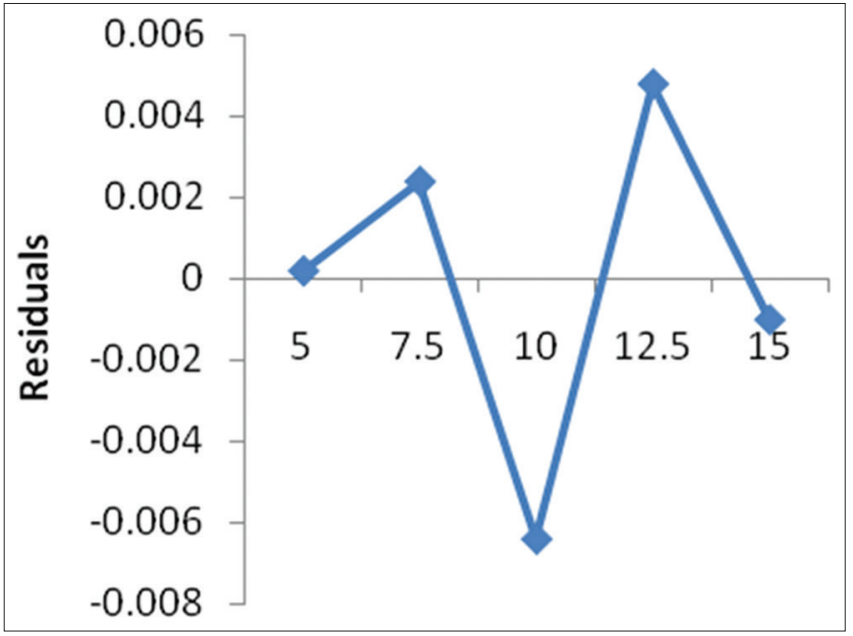

Fig. 13: Residual plot at $243 \mathrm{~nm}$

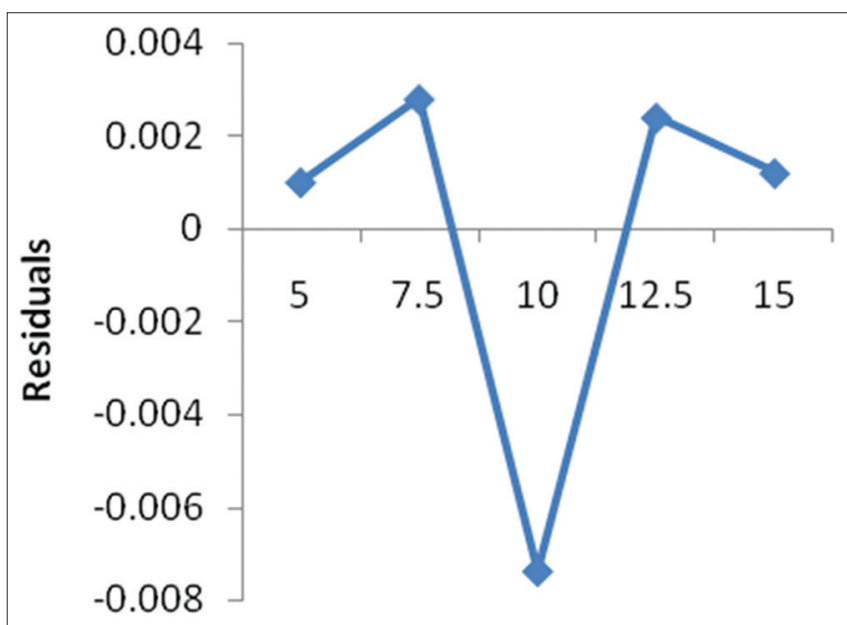

Fig. 14: Residual plot at $245 \mathrm{~nm}$

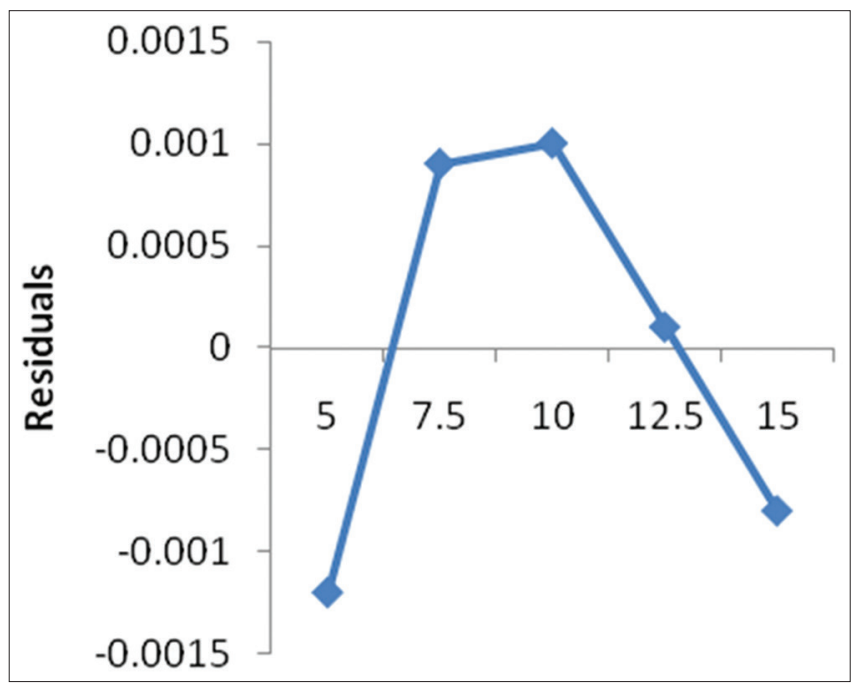

Fig. 15: Residual plot at $247 \mathrm{~nm}$

\section{Precision}

Intra- and inter-day precision studies were carried out. The percentage RSD values for intraday and interday precision were found to lie within the range of $0.473-1.373$ and $0.301-1.617$ which was found well within the acceptance criteria of $<2 \%$ at all the selected wavelengths. The low

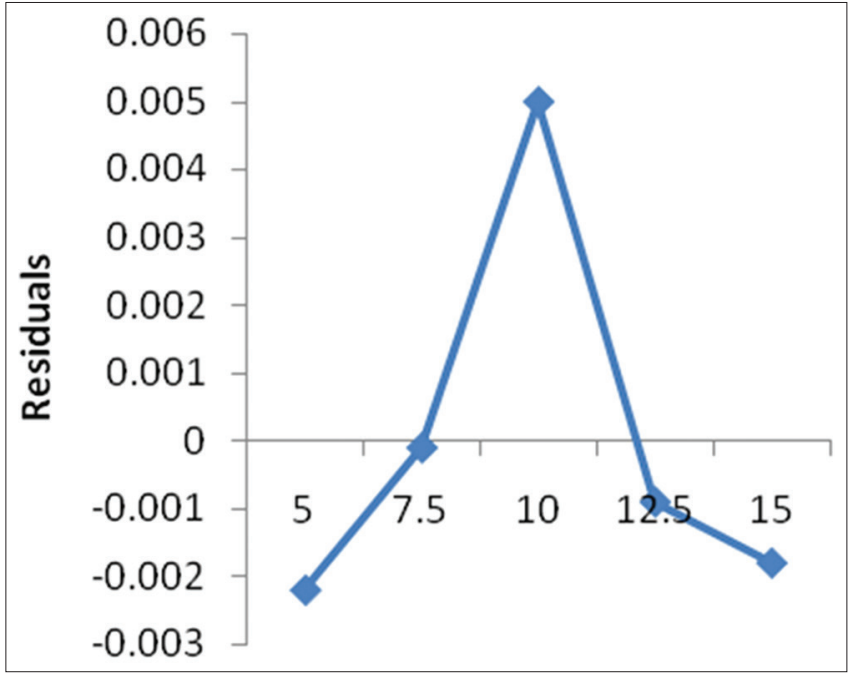

Fig. 16: Residual plot at $249 \mathrm{~nm}$

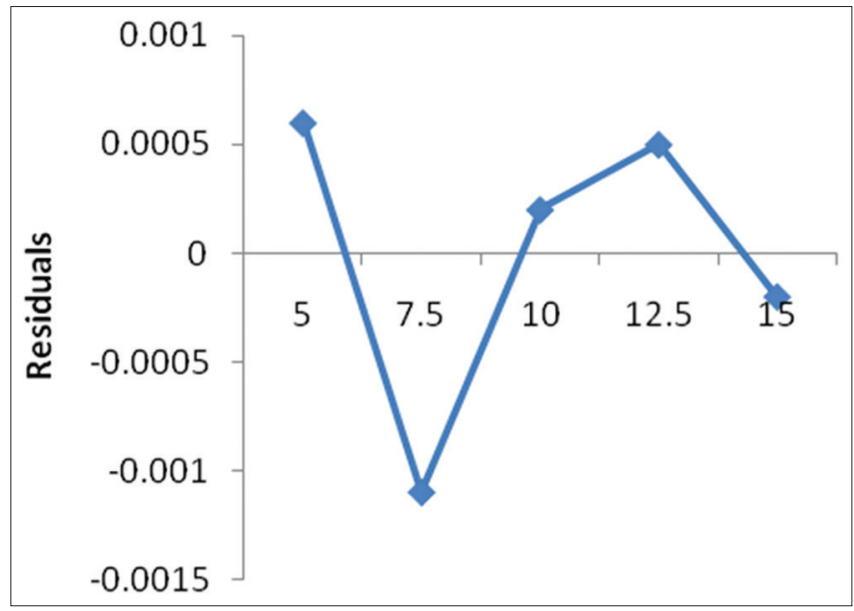

Fig. 17: Residual plot at $251 \mathrm{~nm}$

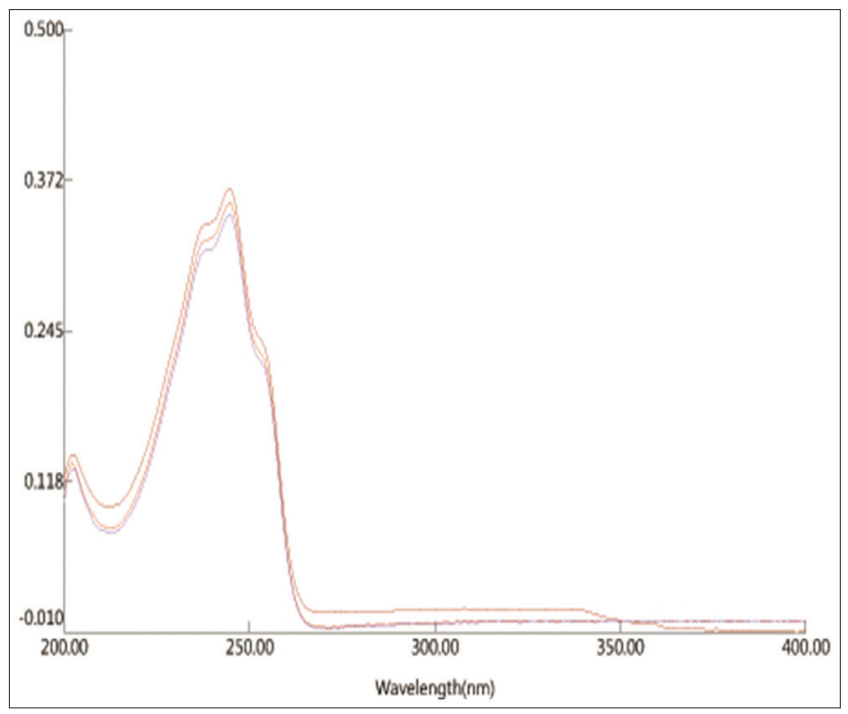

Fig. 18: Overlay UV spectrum showing intraday precision

percentage RSD values indicate that the suggested method was precise. The results of precision study were represented in Figs. 18-19 and tabulated in Tables 3-6. 
Table 8: Recovery studies

\begin{tabular}{|c|c|c|c|c|c|c|}
\hline $\begin{array}{l}\text { Wavelength } \\
(\mathrm{nm})\end{array}$ & $\begin{array}{l}\text { Concentration } \\
\text { levels }(\%)\end{array}$ & $\begin{array}{l}\text { Final concentration } \\
(\mu \mathrm{g} / \mathrm{mL})\end{array}$ & $\begin{array}{l}\text { Amount present } \\
(\mu \mathrm{g} / \mathrm{mL})\end{array}$ & $\begin{array}{l}\text { Amount added } \\
(\mu \mathrm{g} / \mathrm{mL})\end{array}$ & $\begin{array}{l}\text { Amount recovered } \\
(\mu \mathrm{g} / \mathrm{mL})\end{array}$ & \% recovery \\
\hline \multirow[t]{3}{*}{239} & 80 & 5 & 4 & 1 & 4.98 & 99.60 \\
\hline & 100 & 10 & 4 & 6 & 9.84 & 98.40 \\
\hline & 120 & 15 & 4 & 11 & 14.86 & 99.07 \\
\hline \multirow[t]{3}{*}{241} & 80 & 5 & 4 & 1 & 4.99 & 99.80 \\
\hline & 100 & 10 & 4 & 6 & 9.85 & 98.50 \\
\hline & 120 & 15 & 4 & 11 & 14.72 & 98.13 \\
\hline \multirow{2}{*}{243} & 100 & 10 & 4 & 6 & 10.01 & 100.10 \\
\hline & 120 & 15 & 4 & 11 & 15.07 & 100.47 \\
\hline \multirow[t]{3}{*}{245} & 80 & 5 & 4 & 1 & 5.09 & 101.80 \\
\hline & 100 & 10 & 4 & 6 & 9.87 & 98.70 \\
\hline & 120 & 15 & 4 & 11 & 14.96 & 99.73 \\
\hline \multirow[t]{3}{*}{247} & 80 & 5 & 4 & 1 & 4.96 & 99.20 \\
\hline & 100 & 10 & 4 & 6 & 9.88 & 98.80 \\
\hline & 120 & 15 & 4 & 11 & 15.09 & 100.60 \\
\hline \multirow{2}{*}{249} & 100 & 10 & 4 & 6 & 9.99 & 99.90 \\
\hline & 120 & 15 & 4 & 11 & 15.07 & 100.47 \\
\hline \multirow[t]{3}{*}{251} & 80 & 5 & 4 & 1 & 5.03 & 100.60 \\
\hline & 100 & 10 & 4 & 6 & 9.85 & 98.50 \\
\hline & 120 & 15 & 4 & 11 & 14.95 & 99.67 \\
\hline
\end{tabular}

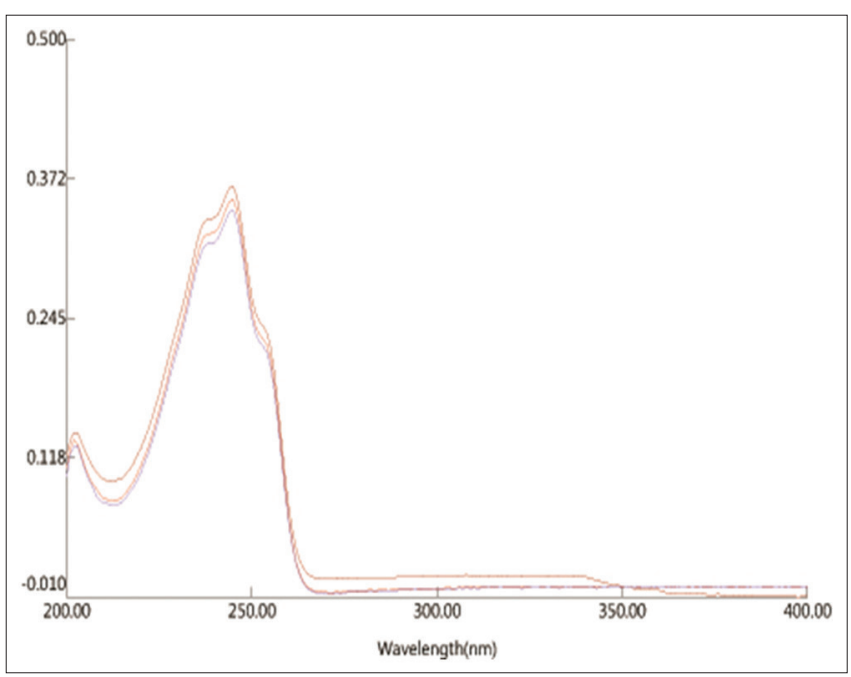

Fig. 19: Overlay UV spectrum showing interday precision

Assay

The absorbance of the extracted sample solution was recorded at $245 \mathrm{~nm}$ and the amount of drug present in the formulation was estimated. The assay percentage of ivermectin (rapimec tablets) was found to be $98.7 \% \mathrm{w} / \mathrm{w}$. The amount estimated in the formulation was found to be $9.87 \mathrm{mg}$ and the percentage RSD value was found to be $<2 \%$ (Table 7)

\section{Recovery}

The percentage recovery of the drug by standard addition method was calculated and was found to be in the range of $97.60-101.80 \% \mathrm{w} / \mathrm{w}$, which was well within the acceptance limit of $97-103 \% \mathrm{w} / \mathrm{w}$ as per the ICH guidelines. Hence, the full-fledged method was found to be accurate. The reports of accuracy study were shown in Fig. 20 and Table 8.

\section{CONCLUSION}

The newly developed spectrophotometric multivariate calibration technique was validated by employing various validation parameters as per the ICH guidelines and was found to lie within the acceptance limits. The method developed in the present study was found to be sensitive,

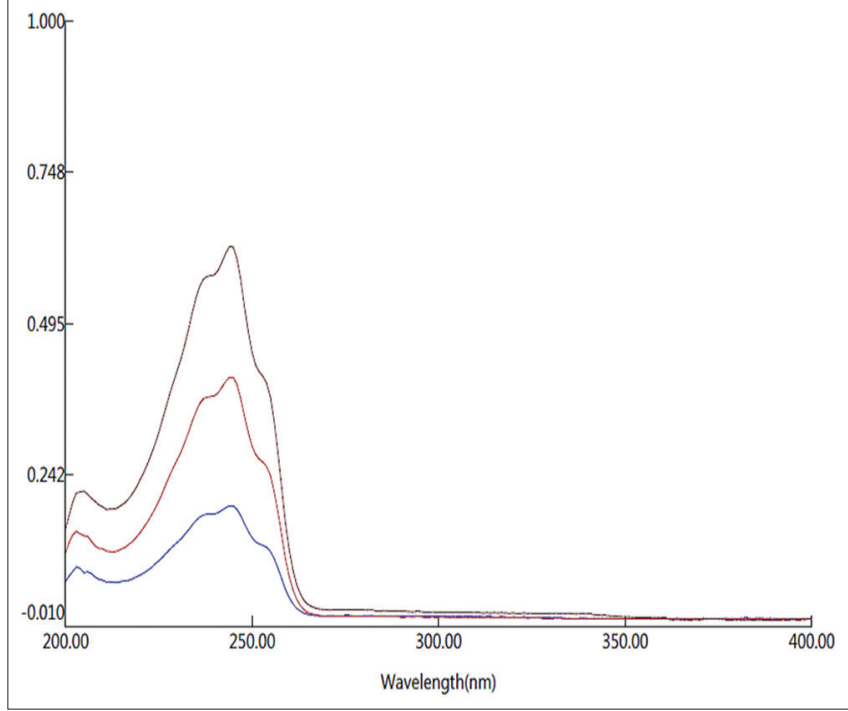

Fig. 20: Overlay UV spectrum displaying accuracy of ivermectin

accurate, precise, and reproducible for the estimation of ivermectin in its tablet formulation. Therefore, a simple and rapid method using mathematical contents was developed, which was found more predictable than the other spectrophotometric methods and is strongly recommended for the routine quality control analysis of ivermectin in pharmaceutical formulations.

\section{ACKNOWLEDGMENT}

Authors are thankful to the Chancellor, SRM Institute of Science and Technology and the management of SRM College of Pharmacy, SRM Institute of Science and Technology, Kattankulathur, and Pondchy Pharmaceuticals, Puducherry, for providing various reprographic sources for carrying out this research work successfully.

\section{AUTHORS' CONTRIBUTION}

All the authors have contributed equally in designing the analysis, for the collection of data, in performing the analysis, and to write the research work in the instructed manner to frame the final manuscript in a successful manner. 


\section{CONFLICTS OF INTEREST}

The authors report on conflicts of interest on the study.

\section{REFERENCES}

1. The Indian Pharmcopoei Commission D. Indian Pharmacopoeia. Vol. 3. Ghaziabad: The Indian Pharmcopoei Commission D; 2010. p. 2662-3.

2. Available from: https://www.pubchem.ncbi.nlm.nih.gov/compound/ ivermectin. [Last accessed on 2018 Jan 12]

3. Roger W, Cate W. Clinical Pharmacy and Therapeutics. $4^{\text {th }}$ ed. Edinburgh: Churchill Livingstone Publisher; 2007. p. 193.

4. Rajiv KC, Anju G. Simultaneous spectrophotometric estimation of albendazole and ivermectin in pharmaceutical formulation. J Pharm Anal 2013;3:11-4.

5. Piotr K, Michal B, Ilona O. Validated capillary electrophoretic method for the analysis of ivermectin in plasma after intragastric administration in pigs and horses. Biomed Chromatogr 2004;18:302-10

6. Kumudini SR, Sunil DR. Validated HPTLC method for simultaneous estimation of ivermectin and albendazole in formulation. Asian J Pharm Biol Res 2011;1:330-6.

7. Pradeep S, Chandrashekar J. Analytical method development and validation for simultaneous estimation of ivermectin and fenbendazole in bulk dosage form by RP-HPLC. World J Pharm Pharm Sci 2016;5:1614-24
8. Meenakshi D, Shanta KL, Manjeet A, Khandal RK. Quantitative determination of ivermectin in raw milk using positive ESI LC-MS/MS. E-J Chem 2010;7:S267-77.

9. Aya S, Tsugiko T. Gas chromatography-mass spectrometric determination of ivermectin following trimethylsilylation with application to residue analysis in biological meat tissue samples. Anal Meth 2011;9:2160-64.

10. Sharma DK, Singh J, Raj P. Spectrophotometric determination of propranolol hydrochloride and metoprolol tartrate in pharmaceutical dosage forms, spiked water and biological fluids. Int J Pharm Pharm Sci 2018;10:107-5

11. El-Didamony AM, Moustafa MA. Direct spectrophotometric determination of atenolol and timolol antihypertensive drugs. Int $\mathrm{J}$ Pharm Pharm Sci 2017;9:47-53.

12. Arayne MS, Najma S, Zuberi MH, Siddiqui FA. Spectrophotometric quantification of metformin in bulk drug and pharmaceutical formulations using multivariate technique. Indian $\mathrm{J}$ Pharm Sci 2009;71:331-5.

13. Kokilambigai KS, Seetharaman R, Kavitha J, Sowndaravel P, Lakshmi KS. Multivariate calibration technique for the spectrophotometric quantification of zaleplon in bulk drug and pharmaceutical formulations. J Pharm Sci Res 2017;9:824-9.

14. International Conference on Hamonisation Quality Guidelines Q2 (R1). Validation of Analytical Procedure, Text and Methodology. Japan and USA: Complementary Guideline on Methodology; 1996. 